\title{
Ireland in the new century
}

At the IAOS's 1909 annual conference, Æ delivered an extraordinary speech in which he accused the movement of lacking 'the vital heat' displayed by nationalist and unionist political organisations at work in Ireland. Fifteen years after the first gathering of delegates $Æ$ used this opportunity to challenge those assembled to consider and question what values initially drew them into the co-operative movement:

We want to find our ideal - the synthesis of all these co-operative efforts. Butter especially when it is good, is a pleasant thing to think about; but you cannot inspire a national movement by calling out, 'Really choicest butter'. Eggs, when they are fresh are a delightful food; but they will not help much to form national ideals, though they may occasionally help to mar them - at election times. So we are driven from the actual character of our rural industries to consider the men who carry them on. It is in our men and in the object of their great endeavours we must find ideals. ${ }^{1}$

Æ stated the profound dilemma that faced Irish co-operators. As editor of the Irish Homestead he possessed a detailed awareness of the impediments and challenges that co-operators encountered at a national and local level. A decade and a half spent promoting the movement and its brand of economic reform saw the enthusiasm for the hard work of social reform replaced by discussions about the quality of produce. That an apparent short supply of idealism existed among members provided a cause for deep concern.

The IAOS's conference occurred on the eve of a general election campaign that revolved around the issue of Home Rule as the question of Ireland's constitutional status within the United Kingdom dominated public debate. Political opinion in Ireland polarised between those who supported nationalist claims for an autonomous Irish parliament in Dublin and unionists who argued for the country's retention within the United Kingdom. ${ }^{2}$ Those who attended the nationwide meetings, which discussed Home Rule, managed 'to lose themselves in their varying ideals of Ireland and Empire. ${ }^{3}$ These political debates drowned out arguments about the need to concentrate upon social and economic questions 
as well as political ones. The production of agricultural food such as butter and eggs remained an immediate aim of co-operative societies, but if co-operators wished to be heard above the political mêlée they needed to stand for more than an improvement in farming methods. If co-operators wanted to retain their relevance they needed to rediscover their sense of missionary purpose or risk marginalisation. Signs of weariness were apparent after a generation of endeavour that saw the co-operative movement grow from a few businesses to a network of societies drawn across rural Ireland. The IAOS's intervention into the rural economy provoked conflict with traders, private dairy businesses and the CWS and this competition cost money. The establishment of the Irish Department for Agriculture and Technical Instruction (DATI) in 1900 provided a welcome source of support in the guise of an annual state subsidy. However, by the time of Æ's speech a breakdown in relations meant that the removal of a state subsidy on which the IAOS had grown reliant threatened to derail the co-operative experiment and undo the previous fifteen years of progress. Shortly before the annual conference, Horace Plunkett wrote to Fr Tom Finlay to emphasise 'the urgent need' that existed 'for a more rapid development of our Movement'. ${ }^{4}$

The conflict between these two leading agencies of rural development, one voluntary and the other governmental, possessed a particular irony as the DATI owed its existence to Plunkett who lobbied and legislated for its establishment in 1900. Plunkett resigned from the IAOS presidency to act as the DATI's first vice-president - the equivalent of departmental head - from 1900 until 1907. As leader of the DATI, Plunkett remained committed to the promotion of cooperation in agriculture and looked to unite the resources of the two institutions to direct agricultural development. As Plunkett's first biographer noted, 'the basic idea underlying the IAOS and the Department had been that they were twin institutions, complementary to one another'.

The co-operative movement emerged as a state-building force in Ireland during the first decade of the twentieth century - one that directly influenced new political institutions. The work to embed a co-operative social blueprint during the 1890s led to the creation of the DATI, which represented the most dynamic institutional development in Ireland before political independence. Moreover, an examination of the relationship between the IAOS and DATI highlights an important way in which co-operators helped to define agricultural policymaking in Ireland. However, this work exposed tensions within the movement about what constituted an acceptable level of collaborative effort with the state - tensions that remained unresolved in this period. The fallout from Plunkett's removal from the DATI proved toxic and sparked a bitter public row between co-operators and departmental officials in the lead-up to the political crisis created by the third Home Rule Bill. The central issue about whether, or not, to support the co-operative movement with public funds became an emotive one around which new political identities coalesced. The hostility shown towards Plunkett and the 
IAOS by the IPP helped a new generation of nationalists define their embryonic political project in opposition to the parliamentary tradition. An attitude expressed in support of the co-operative movement could serve as a proxy for whether someone supported an alternative national project to that put forward by the constitutional nationalists; what Roy Foster termed 'new nationalism'.

The efforts of co-operative activists to re-make Irish society have repeatedly been overshadowed within the historiography by a focus upon the 'white heat' caused by dramatic political and military developments. Although these developments were eye-catching, this focus overlooks the way in which radical change had been gestating at the mundane level at which the co-operative movement primarily operated and through which it contributed to a new nationalist political economy. The split between the DATI and IAOS highlighted the intersection of political and economic ideas within Irish nationalism that became more prominent after the 1916 Easter Rising. The nominal wrangle over funding exposed two incompatible governmental visions for rural development at play before the outbreak of the First World War. The social conflict generated by co-operative economics held repercussions beyond the battle to define a template for agricultural progress. Instead, co-operative ideas fed directly into a wider process of nationalist renewal.

\section{The Department of Agriculture and Technical Instruction for Ireland}

The relationship between co-operative movements and the state frequently provoked debates about what constituted a proper relationship. Co-operative activists maintain that an ethos of self-help promoted a spirit of economic autonomy among members. However, some co-operators argue that co-ordinated state support can amplify the effectiveness of co-operative activities, while others view the state as a threat to the voluntary nature of co-operation. For Lionel SmithGordon, who conducted a review of co-operation across different national contexts for the Irish movement, the success of the Danish co-operative dairying sector provided 'an example of the right way of combining State encouragement with the principle of self-help'. The Danish state exercised 'its authority only to give effect to what is already the policy approved by the organised co-operators. It gives a legal sanction to what the co-operators have already decided.' ${ }^{\text {T This belief }}$ animated the work of Horace Plunkett in the early twentieth century, but it was a statist enthusiasm not shared by many of his allies.

The politics of co-operation and state assistance acted as a source of long-standing controversy in Ireland during the first decades of the twentieth century. For his part, Plunkett stressed the importance of 'the resources of self-help' in furthering co-operation. However, he tempered this view on account of continued vigorous competition from foreign producers, which meant that the movement needed its 'voluntary efforts supplemented with a reasonable measure of State aid'. ${ }^{8}$ More 
importantly, the co-operative movement generated a momentum that influenced the way in which the state functioned in rural Ireland. As the American economist David McCabe observed, the existence of the IAOS 'led directly to the creation of a Department of Agriculture and Technical Instruction for Ireland by voicing the demand for such a department, and organizing the farmers in a way to enable them to take full advantage of state aid to their industry. ${ }^{\text {? }}$

The type of developmental work undertaken by Irish co-operators at the end of the nineteenth century saw it act as a surrogate for the state. The IAOS carved out a role whereby it augmented the work of existent state bodies to deliver under-resourced services. For example, the IAOS looked to improve the levels of education among the agricultural classes. The IAOS petitioned the government in 1896 to instruct the Commissioners of National Education to appoint a travelling Dairy Expert, but the position remained unfilled. ${ }^{10}$ Already IAOS organisers partly provided such a function as they 'found it necessary to undertake a good deal of directly educational work, including a considerable system of Technical Instruction, in order that the Societies ... may be properly able to fulfil the industrial purposes for which they have been formed'. ${ }^{11}$ From the start the IAOS looked to harmonise its organisational work with the Congested Districts Board (CDB), which was designed to deal with rural poverty and improve social and economic conditions along the western seaboard. ${ }^{12}$ Plunkett served as a member of the CDB and facilitated collaboration. In 1895, the CDB subscribed $£ 200$ to the IAOS 'for the purpose of organising Agricultural Co-operative Societies in Congested Districts'. CDB inspectors could help with the initial stages of co-operative organisation. One CDB inspector, Major W.P. Gaskell, engaged in co-operative work and although he 'encountered very great difficulties... [he] succeeded in forming two Societies at Bohola and Killasser, both in the Swinford Union'. ${ }^{13}$

A year after the IAOS's foundation Plunkett looked to build upon that achievement by engineering political agreement over the devolution of agricultural policymaking from Westminster to Dublin. The subsequent foundation of the DATI in 1899 represented a landmark in Ireland's political history and evidence of Plunkett's tenacity as he introduced a second major agency of agricultural progress to Ireland. Although described by critics as 'the Institution that teaches hens how to lay eggs', the Department helped to develop the theory and practice of Irish agriculture. ${ }^{14}$ Plunkett used his influence as IAOS President and MP to fashion a coalition of political interests that established the DATI. His first step was to establish the Recess Committee of 1896, which he chaired. The Recess Committee sat as an informal, ad hoc cross-party group of parliamentarians who agreed to discuss the possibility of a separate Irish Board for Agriculture. The deliberations brought together nationalists and unionists and committed no party to any particular policy. John Redmond, the leader of the IPP's Parnellite faction, participated on the understanding that its findings might strengthen demands 
for Home Rule in the long term. ${ }^{15}$ The Committee issued a final report which advocated the transfer of political powers over agricultural and educational legislation from Westminster to a department in Dublin. An Act of Parliament passed in 1899 created the DATI for this purpose. ${ }^{16}$ Plunkett found himself pushing at an open door in his campaign to devolve the powers of agricultural policymaking. As Theodore Hoppen argued, the incumbent Conservative administration tended to 'prop up Irish policy upon cushions of government cash'. ${ }^{17}$ Some observers argued that the decision amounted to Home Rule for Ireland in agricultural policy, while others saw the decision in keeping with a wider policy programme which consisted of 'an integrated doctrine of strong government and social amelioration'. ${ }^{18}$

The DATI opened on 1 April 1900 and assumed responsibility for a number of tasks: the collection of agricultural statistics; the regulation of markets, fairs and fisheries; monitoring animal diseases; and the administration of the National Library, National Museum, National Botanic Gardens, Geological Survey and Metropolitan School of Art. The major advancement concerned new powers to introduce measures to stimulate agriculture, technical instruction and rural industry. A capital sum of $£ 200,000$ and an annual endowment of $£ 166,000$ gave the new department significant leeway to effect wide-ranging agricultural reforms. ${ }^{19}$ Moreover, for the first time Irish politicians possessed real political power to dictate substantive policy in the field of rural development. Plunkett's reward saw him appointed as Vice-President of the DATI (effectively the departmental head as the presidency remained a ceremonial title reserved for Ireland's Chief Secretary). Prior to 1900 Plunkett used his position as Recess Committee Chair to argue that co-operation proved the most effective agent of agricultural improvement, with his movement identified as 'the chief lever of progress' ${ }^{20}$ Horace Plunkett led the DATI between 1900 and 1907, which marked the start of a collaborative relationship between the state and the co-operative movement to reorganise the Irish countryside.

The DATI immediately asserted its position as an autonomous voice for Irish industrial development by taking part in the 1901 International Exhibition in Glasgow. The Department erected an Irish pavilion at the exhibition which displayed 'a representative selection of the characteristic products of Irish Industry'. A handbook that highlighted Irish industrial and natural potential accompanied the exhibition. In his preface to the collection, the head of the DATI's Statistics and Intelligence Branch, William Coyne, singled out 'the splendid work done by some of the great voluntary associations of Ireland in developing the material resources of this country. ${ }^{21}$ The wide-ranging collection of essays included pieces on co-operative dairying and credit.

The DATI and IAOS co-ordinated workloads under Plunkett's influence. For example, the DATI assumed responsibility for the practice of surprise butter competitions which saw inspectors take samples of butter from random creameries 
to test. ${ }^{22}$ Such practices encouraged creamery managers to promote high-quality butter manufacturing and farmers to supply unadulterated milk. The experience of early fruitful collaboration convinced Plunkett of the function of the state as a crucial component of fuller co-operation. In a speech to the National Cooperative Festival held at Crystal Palace, London, in August 1901, Plunkett conceded the need for a strategic relationship between co-operators and the state. The leadership of the Irish co-operative movement realised that in addition to organised self-help ... the economic condition of the country required a measure of State aid'. Plunkett viewed this 'not ... as a substitute for, but as a stimulant and supplement to, associated effort. The DATI provided a potent instrument to achieve the dissemination of this idea.' One such economic condition was that of rural emigration, which required serious action. Plunkett contrasted Irish population decline with that of mainland Britain, telling British co-operative delegates that 'our population is melting away as fast as yours is being reinforced'.

However, the problem proved more serious than numerical decline, as Plunkett outlined: 'the drain from Ireland is worse from the standpoint of quality ... The active and the enterprising leave us with an undue proportion of the very old and very young, of the mentally and physically unsound. ${ }^{23}$ This linkage of population decline to the physical and psychological atrophy of the rural population would remain part of the critical discourse about emigration throughout the twentieth century. ${ }^{24}$ By strengthening a co-operative economy, Plunkett hoped that enough Irish people would remain to work in a more industrious countryside.

The DATI's second Annual General Report officially recognised 'the great importance, for the development of agriculture and industries and the improvement of social life in Ireland, of Co-operative Societies of farmers and other producers' ${ }^{25}$ The arrangement between state and co-operative sector provided the IAOS with opportunities to supplement the organisation's income. In 1902, P.J. Hannon and $Æ$ earned 'a considerable sum over and above their salaries' for the IAOS by taking part in the DATI's Pioneer Lecture Scheme. ${ }^{26}$ The presence of co-operative societies provided a platform through which information about legislation and agronomical science could be disseminated to large numbers of farmers. Lectures by agricultural experts were organised with the assistance of local societies. For example, in 1904 the IAOS distributed a series of circulars to its societies that informed members about a range of official matters. These included: changes to regulations relevant to co-operative credit societies and the payment of stamp duty; recommendations about obtaining fire insurance for co-operative buildings; directions to IAOS creamery managers to ensure they met a certain level of qualifications and book-keeping standards; and intelligence reports on butter prices and markets. ${ }^{27}$

Some viewed the IAOS and DATI as inseparable. In July 1902, Lismore Rural District Council in County Waterford passed a resolution whereby it endorsed the work of the IAOS and recommended farmers in the district to 
start their own co-operative creameries and corn stores. The Council passed a resolution that requested both the 'Irish Agricultural Organisation Society and the Department of Agriculture be requested to send down lecturers to point out to the farmers of the district the advantages of co-operation when they are properly organised'. The IAOS agreed to offer its assistance to the farmers of Lismore after the Council's invitation. The request for such assistance opened up new possibilities for co-operative development as Robert Anderson used this opportunity to write to all Rural District Councils 'to take up similar work elsewhere'. ${ }^{28}$ The IAOS's association with the DATI provided the movement with a new official prominence.

The collaboration between voluntary and state agencies bore some extraordinary results. In 1905, the establishment of a Home Industries Co-operative Society and Gaelic League branch in the village of Dromore, County Tyrone, provided evidence of the efficacy that co-operation between different organisations provided in the efforts to revitalise communities. Praising Plunkett, The Irish Homestead reported that:

we doubt whether even he saw so deeply into Irish necessities as when, in conjunction with [local priest] Father Maguire, he undertook to make one parish in Ireland a model parish, and let loose three great agencies, the IAOS, the Gaelic League, and the Department upon the work.

Diffusion of the co-operative model required concerted action between not only national agents such as the IAOS and Gaelic League, but also local influential brokers such as the clergy. On occasion this social co-operation produced cordial relations that transcended traditional sectarian divisions. To highlight this effect, the Homestead's report on Dromore concluded with an incident that demonstrated mutual respect between local nationalists and unionists: 'We are credibly informed that at the last twelfth of July celebrations the Orangemen of Dromore asked for the loan of some Nationalist drums and their use was cheerfully allowed for the occasion. ${ }^{29}$

However, if the principle of co-operation enabled warm relations across some local communities, these effects did not extend across the political sphere. As joint action bore some results the IAOS published a leaflet titled 'Home Rule in the Dairy. ${ }^{30}$ The appropriation of nationalist rhetoric provided constitutional nationalists with an uncomfortable reminder that Plunkett, a one-time Unionist MP, achieved a significant degree of political devolution for Ireland which they had yet to do. Plunkett was a figure of contempt for many nationalists. John Dillon, a leading Nationalist MP, pursued a campaign against the co-operative movement, and Plunkett in particular, in Parliament. Dillon believed the movement's attempts to attain social and economic improvements eroded 'the very substance of the nationalist movement'. It did this by concentrating upon improving material conditions for rural people and weakening demand for an Irish Parliament. 
Any attempts to further the co-operative movement's influence - which, Dillon argued, the DATI achieved - should be resisted..$^{31}$

In 1906, the IAOS came under severe scrutiny at an agricultural inquiry organised by the government in response to pressure from Nationalist MPs. The report sought to resolve the anomaly of the Vice-President of the DATI sitting in office without a parliamentary seat. The final report concluded that 'while it is necessary that the Department should be represented in Parliament it is neither necessary nor desirable that it should be represented by the Vice-President'. ${ }^{32}$ However, the inquiry revealed the vulnerability of Plunkett's position. Opponents to co-operation used the occasion to criticise how the relationship between the DATI and IAOS unfairly placed public funds at the disposal of the co-operative movement. At the session held in Limerick on 3 July 1906, a sequence of witnesses drawn from local government and business lined up to highlight the damaging effect levelled at private agricultural businesses by the IAOS. William McDonnell JP, Alexander Shaw JP and Thomas Cleeve from Limerick's Chamber of Commerce, Patrick Vaughan JP and Chairman of Limerick County Council, and J. McInerney from the Board of Guardians all attacked the IAOS and criticised the DATI's provision of a state grant to the co-operative movement. Thomas Cleeve, a Canadian businessman who owned the Condensed Milk Company based in Limerick and with over fifty branches throughout the south-west of the country, argued that 'it is regarded as unfortunate to traders and proprietors that Sir Horace Plunkett was appointed Vice-President' of the DATI. The fact he 'was so strong on co-operation' meant that he placed 'in at least second place the industries long in existence before his advent as the chief of the Irish Agricultural Organisation Society'. Plunkett used this position to promote a 'programme of co-operation before all others. It is truly a lamentable state of things that in the 20th century Great Britain would lend herself indirectly to the long-continued failing she had of destroying our established industries. ${ }^{33}$

In response, the Inquiry provoked a strong reaction from many co-operative societies who publicly moved to defend their umbrella organisation. One such resolution, published by the committee of Abbeydorney Co-operative Society in north Kerry, summarised the positive effects co-operative organisation brought to the farmers of the district:

1 It has raised the value of our produce fully 25 per cent, as compared with Cork market prices, which we had to depend on formerly.

2 That the co-operative creameries have both improved the quality and increased the quantity of our butter.

3 That by co-operation we have been brought into touch with the best markets for our produce, and have thus secured a very good, if not the top, price.

4 That if by any misfortune, while the movement is still young, it should be deprived of the benefits of co-operative organisation and left to the tender mercies of the merchants as formerly, we believe prices would fall heavily, and our industry be ruined in a short time. ${ }^{34}$ 
The spread of co-operative principles brought technological improvements and expert guidance in a way many farmers recognised. One troubling implication of the breakdown in the IAOS and DATI's relationship was that co-operators would be forced to rely more upon their own resources.

From the outset, Plunkett demonstrated an awareness of the shaky foundation of his position at the helm of the DATI. Plunkett's leadership relied upon the Westminster government's discretion as he lost his parliamentary seat at the 1900 general election. He explained this loss on 'the fact that co-operative education has so demoralised my politics that I am a political outcast'. ${ }^{35}$ Plunkett's time as Departmental head saw him attract severe criticism. As discussed earlier, the publication of Ireland in the New Century generated a public backlash against Plunkett that further weakened his position at the DATI. ${ }^{36}$ His lack of a parliamentary seat left him vulnerable to attack from rivals. Dillon criticised the link between the IAOS and DATI, and questioned the Attorney-General over 'what steps he proposes to take to prevent the continuance of this illegal action'. ${ }^{37}$ The Attorney-General confirmed the legality of the relationship, but politically, Plunkett's position proved untenable. The collaboration between the IAOS and the DATI ended in 1907, when Plunkett's political opponents forced him from office. $^{38}$

\section{The Department of Agriculture and Technical Instruction after Plunkett}

Any attempt to create a rural hegemonic project around the twin pillars of the IAOS and DATI stalled in 1907 with the replacement of Plunkett by Thomas Wallace Russell as Vice-President of the DATI. Russell was a Liberal Unionist MP from Tyrone who supported tenant farmers rights. With the passage of Wyndham's Land Act in 1903 and John Redmond's pro-imperialist leadership of the IPP, Russell's opposition to Home Rule softened. He represented a palatable candidate for the departmental leader and received the support of the IPP in this role. ${ }^{39}$ Russell directed the DATI for the next eleven years until his retirement after the First World War and implemented policies that improved Irish fisheries, conducted forestry research and experimentation and counteracted a widespread outbreak of foot-and-mouth disease in $1912 .{ }^{40}$

Plunkett's removal from the DATI provoked consternation among local cooperative societies and committees across the country published resolutions that highlighted widespread dismay at the severed connection between the IAOS and DATI. One co-operative society encapsulated a mood that the rupture ended a period of vital state support for the movement:

That in a country so educationally backward as Ireland, the spontaneous growth of self-help cannot be expected as yet; we therefore consider that it is the duty of the Department of Agriculture to provide the means for extending the co-operative principle among farmers, it having proved to be the most effective form of practical education. $^{41}$ 
While the end to the IAOS and DATI's partnership demoralised Plunkett, others welcomed the separation. At the 1907 Annual General Meeting Fr Finlay declared that the movement now went forward 'imbued with the proper spirit - the spirit of co-operation applied on the scale on which federations were built up'. Finlay argued that organisers needed to restrict their focus to societies already in existence to guarantee co-operation carried on in the 'proper spirit'. ${ }^{42}$ In response, the IAOS directed its resources towards the consolidation of current position, which bred a more conservative movement unwilling to risk expansion.

The separation also encouraged members to express their enthusiasm for new-found economic autonomy in highly nationalistic terms. Mr Scully, a delegate from Clonlisk, County Offaly, viewed the separation of the IAOS and DATI as an opportunity to demonstrate the movement's strength:

They were too long begging and craving from the Government, and that was what left Irishmen as they are. (Laughter) It was time the co-operators of Ireland began to do their own business. Let them prove to the department and to their enemies that they were able to do it (hear, hear), and when their enemies saw that they were able to do for themselves those enemies would become their friends. ${ }^{43}$

Scully exemplified a view among co-operators that the IAOS's relationship with the state eroded the self-reliance principle and viewed the DATI's interference as inimical to the long-term realisation of the movement's goals. A suspicion of the British state in Ireland began to creep into the attitudes of Irish co-operators over the next decade.

T.W. Russell's appointment created immediate friction between the IAOS and DATI. With Russell at the helm of agricultural development, critics of the cooperative movements such as IPP representatives and traders looked to force a retreat of the co-operative sector's role in agricultural production and distribution. Robert Anderson described Russell as an individual who 'hated the IAOS because his trader and political allies feared it'. ${ }^{44}$ The Times described Russell, while in office, as someone who 'fought the [Irish Agricultural Organisation] Society with extraordinary bitterness and has shown much perverted ingenuity in opposing its claims and crippling its work' ${ }^{45}$ Russell made his antipathy towards the cooperative movement clear from the start and stressed that, under his leadership, 'there would be no partnership between the IAOS and the Department' and he instituted a policy of 'non-controversial co-operation'. ${ }^{6}$ 'The 'non-controversial' part of this policy referred to the official objective that co-operative societies should continue to trade only if they refrained from harming the interests of local independent and private operators. ${ }^{47}$

On 19 November 1907, Russell delivered his first speech to the DATI's Council of Agriculture, which set out his first priority to redefine the relationship between the IAOS and Department. As he tackled the 'serious controversy' he chose as his theme the unfairness of the annual allocation of $£ 3,700$ to the IAOS from 
public funds. While he understood that the IAOS promoted the 'genuine work of agricultural co-operation' in dairying and agricultural production he objected when co-operators 'go outside the farmer's business altogether, and actually try to turn farmers into shopkeepers'. The practice of creameries and other societies performing ad hoc retail services meant farmers got 'into competition with the ordinary shopkeepers', which Russell declared meant 'I, for one, will be no party to a penny of the Department's money going to promote co-operation of this kind'. ${ }^{48}$ Russell proposed that the 'annual subsidy paid to the Society by the Department should not be continued'. The proposal passed with the grant eventually phased out. ${ }^{49}$ The Irish Homestead report of the speech suggested they hoped to change Russell's mind on the matter in the near future: 'Mr Russell will learn the facts of the work of the IAOS later on, and we are sure he will prove a good friend as one misconception after another is cleared away. ${ }^{50}$

Such hopes proved to be misplaced. The subsidy to the IAOS from the DATI ceased on 1 January 1909. Moreover the official connection between the bodies ceased when the DATI decided to end the arrangement whereby two of its officials attended the IAOS General and Executive Committees. ${ }^{51}$ From this point onwards the IAOS moved to the margins of official agricultural policymaking and presented itself as an embattled movement under attack from powerful enemies at the DATI.

Sensing the hand of political forces behind the direction of this new agricultural policy Æ used the Irish Homestead to attack the Nationalist Party at Westminster. In particular, $Æ$ accused John Dillon of a 'misrepresentation of facts' when he spoke of Plunkett and the co-operative movement in Parliament. Æ criticised Dillon's narrow focus on constitutional politics at the expense of social and economic issues:

Without organisation in this sense Mr Dillon might finally have got his Parliament in College Green [Dublin] and found rural Ireland economically controlled and enslaved by bodies like the English Wholesale Society.

A co-operative political economy in practice offered an alternative conception of independence based on economic autonomy which $Æ$ defined as 'Industrial Home Rule'. ${ }^{2}$ The IAOS's work to counter trade bodies such as the CWS contributed more to the liberty of Irish farmers than any campaign for a Home Rule Parliament up to that point.

Some at the IAOS privately welcomed the separation of movement and state. Robert Anderson and Fr Finlay viewed the relationship's end as potentially positive. Anderson, who held deep reservations about collaboration between the voluntary and state sectors, 'could see no good in a State-controlled IAOS which would be virtually an outside branch of the Department which subsidised it' ${ }^{53}$ At the first IAOS conference after Plunkett's removal from the DATI, Finlay's vicepresidential address elucidated his optimism for the movement. Finlay believed 
that the combined efforts of the DATI and IAOS to develop agriculture brought about a 'paralysis' among co-operators. Reliance upon the DATI subsidy encouraged the belief

that the work in which [co-operative activists] were engaged had been taken up by the State, they considered themselves absolved from vigorous activity in prosecuting it, and that was specially the case in a movement which, by its nature, was to be promoted chiefly by individuals whom it benefitted. They were now returning to the condition in which they must rely entirely upon themselves. They might have to face difficulties, but for himself he looked forward with confidence to the future. (Applause.)

Not all co-operators agreed with this assessment. HF Norman, an IAOS official and former Homestead editor disagreed with Finlay and argued that the relationship between the DATI and IAOS had proved beneficial for co-operators. ${ }^{54}$ The extent to which the state's role in co-operation was desirable provided a longstanding source of controversy.

One immediate loss of prestige for the IAOS was its inability to use its acquired expertise to influence departmental investigations that looked into the economic conditions of Irish agriculture. Under Plunkett's leadership, DATI reports received significant input from a range of agricultural experts and included an advocate from the co-operative movement. One example was an investigation in 1903 into ways the Irish dairy industry might end the adulteration of butter while countering the threat to butter producers from the sale of cheap margarine labelled as butter. Plunkett chaired the investigative committee, which included Robert Anderson as the IAOS's representative alongside a range of public health officials, trade body representatives and politicians. The investigative committee cross-examined a number of experts from countries that included Holland, Denmark and the United States. The final report recommended the need for some form of control and regulation over produce and greater international co-operation between countries to achieve this goal. ${ }^{55}$

The DATI investigated the condition of the dairy industry once again in 1910 . A major focus of this examination focused upon the various trade descriptions applied to different grades of Irish butter sold across the United Kingdom. This time the investigating committee included no IAOS representative. ${ }^{56}$ The committee did cross-examine Robert Anderson, whose evidence drew upon his long experience at the largest trade organisation in the field of butter production. Anderson revisited some of his 1903 arguments that 'creamery butter remained too loosely defined' and greater legislative regulations were required as lower-quality butter made within households continued to be sold as creamery produce. Anderson suggested three clear proposals that the DATI could implement to improve the international reputation of Irish butter, but crucially, any effective scheme needed the co-operation of the IAOS as the largest corporate body in the industry. The 
proposals included repeated calls to encourage winter dairying alongside the introduction of cow testing facilities to improve the quality of cattle stocks. His final proposal was the 'formation of an "Irish Co-operative Creamery Control"' to establish and maintain a high level of excellence in butter production. ${ }^{57} \mathrm{He}$ ended his evidence on the hopeful note that he felt

confident that the Department, so far from placing any obstacles in their way, will cheerfully and cordially co-operate with the co-operative creameries and with the IAOS in supplementing and seconding any useful and practical effort which may result from the greater manifestation of the spirit of self-reliance and self-help. ${ }^{58}$

The final report ignored Anderson's evidence. In a summary description of the people and organisations from which the committee received input, the co-operative movement appeared as an afterthought:

Creamery proprietors and managers, owners of butter factories, merchants of Belfast, Dublin, and Limerick, farmers who make butter on their own farms, delegates of the Cork Butter Market trustees, of the Irish Butter Trade Association, of the Irish Creamery Managers' Association, and of the Irish Creameries Protection Society. We have also received evidence on the subjects of our inquiry from the Irish Agricultural Organisation Society. ${ }^{59}$

The only substantive mention made of co-operative creameries in a final report that looked at Irish dairying offered a jaundiced assessment of their work as 'extremely lax in the discharge of their duties'. Co-operative managers lacked the sufficient interest in 'such important matters as costs of production, cleanliness of the milk supply, prices realised for their produce, and other conditions upon which the success or failure of the creamery depends' ${ }^{60}$ Rather than view co-operative creameries as the major point for legislative reform the report betrayed an official attitude that these societies represented an impediment to progress.

At the local level the work of organisers continued to keep the co-operative movement functioning while personalities at the elite end of the dispute between the DATI and IAOS wrangled over funding. The co-operative business model continued to increase its appeal among the rural population during this period of apparent crisis. Between 1907 and 1914 the number of societies affiliated to the IAOS experienced some fluctuations but overall the trend was one of continued growth in terms of membership. At the point of the split with the DATI in 1907, 913 co-operative societies, with a total of 82,311 members, belonged to the IAOS. By the outbreak of the First World War, these figures had increased to 1,023 co-operative societies and membership figures reached 106,212 (table 3.1).

Organisers continued to work towards Plunkett's ideal of 'Better Business' by promoting educational improvement at the society level. Disassociation from 
Table 3.1 Co-operative societies and members, 1907-14

\begin{tabular}{lcr}
\hline Year & $\begin{array}{l}\text { No. of societies (creameries, } \\
\text { credit societies, etc.) }\end{array}$ & Membership \\
\hline 1907 & 913 & 82,311 \\
1908 & 881 & 85,939 \\
1909 & 835 & 91,661 \\
1910 & 880 & 94,512 \\
1911 & 934 & 97,318 \\
1912 & 947 & 101,991 \\
1913 & 985 & 104,702 \\
1914 & 1,023 & 106,212 \\
\hline
\end{tabular}

Source: IAOS, Annual Reports, 1907-1914.

the DATI limited this aspect of their work. Nevertheless, organisers continued to visit societies in order to diffuse new agrarian techniques to help farmers to remain competitive. For example, in December 1913, the IAOS organiser suggested to Abbeydorney Co-operative Society in County Kerry that they invite Thomas Wibberley, an eminent agrarian expert to address their farmers on the topic of 'continuous cropping, and the production of milk in Winter'. ${ }^{61}$ Wibberley, an agricultural lecturer, had published pioneering work on farming methods and offered advice to farmers in the nearby districts of Ardfert and Lixnaw.

The IAOS organiser ensured the IAOS retained a key role in driving economic development in the countryside during this period. The organisational team's size reflected the stretched financial resources of the IAOS. In 1907 the IAOS Executive restructured its team of eight organisers and relied upon this small staff to communicate their views of the grass-roots membership back to Dublin. The IAOS assigned each individual to a geographical area (table 3.2). ${ }^{62}$ The benefit of assigning organisers to specific regions meant they accumulated detailed local knowledge and provided a recognisable point of contact for societies. This gave the organiser important symbolic capital within their districts, which helped them to resolve local disputes and problems. In 1913 a visiting American Commission established to investigate agricultural co-operation overseas described the IAOS organisers as 'the hardest worked people in Ireland'. It also took an outsider's perspective to credit the IAOS with the provision of an invaluable service for farmers in spite of the controversies in which they became embroiled. Following a four-day visit to Ireland in July 1913, the Investigative Commission concluded that the movement had achieved 'good work, which the founders of the movement may well look on with pride, and those who gave it support may regard their money as well invested ... The change of feeling in the country has been effected.' ${ }^{63}$ 
Table 3.2 Structure of organisational staff, 1907

\begin{tabular}{ll}
\hline Name & Responsibility \\
\hline $\begin{array}{l}\text { Mr C.C. Riddall } \\
\text { Mr P. Gregan }\end{array}$ & $\begin{array}{l}\text { Counties Cork, Kerry, Limerick and Waterford } \\
\text { Counties Mayo, Leitrim, Roscommon, Longford, Westmeath } \\
\text { and King's } \\
\text { Counties Donegal (Flax Societies), Derry, Antrim, Down, } \\
\text { Tyrone and Armagh }\end{array}$ \\
Mr M. Joy & $\begin{array}{l}\text { Counties Louth, Meath, Dublin, Kildare, Carlow, Queen's, } \\
\text { Kilkenny, Wicklow and Tipperary }\end{array}$ \\
Mr M.A. Lyons & $\begin{array}{l}\text { Counties Galway and Clare } \\
\text { Mr J. Moore }\end{array}$ \\
Miss Reynolds & $\begin{array}{l}\text { Counties Cavan and Monaghan } \\
\text { Mr M.J. Hickey }\end{array}$ \\
\hline
\end{tabular}

Source: IAOS, Annual Report, 1908.

\section{Co-operation and the Development Commission}

T.W. Russell's vice-presidency saw the DATI promote a rural political economy that aimed to roll back the influence of co-operative ideas. The discontinuation of the annual grant in 1909 placed immediate strain on the IAOS's resources. After this date IAOS remained financially vulnerable with its work 'sadly hampered by lack of funds'. ${ }^{64}$ This loss of funding encouraged conservatism within the movement as priorities shifted from expanding the repertoire of co-operative activities to the maintenance of a healthy creamery sector. The importance of private donors to the continuation of the IAOS's work proved to be most crucial at this point. The IAOS appealed for higher contributions from its societies to meet this shortfall. However, the level of contributions failed to match expectations. In 1910 the funds raised amounted to $£ 4,708$. Of this total, $£ 2,417$ came from individual subscriptions. The total amount raised from the co-operative societies only amounted to $£ 1,230$. $^{65}$

To compound matters further, Russell used his position as an ex-officio member on the CDB to reduce the limited financial assistance granted by that body to the IAOS. According to the CDB's Secretary, William Micks, Russell appointed a committee to review the use of public money to fund co-operative credit societies. During 1898 to 1910 the CDB lent $£ 7,345$ to co-operative banks which provided seed capital to farmers for small-scale developmental projects on the western seaboard. When the Committee reported 'in favour of recalling all loans made out of public money to the Banks', the CDB 'felt obliged' to recall these loans made to co-operative banks. All money was repaid with interest except for one sum of three shillings and one penny. Micks recalled that Russell 
'felt very strongly on the subject and was provocative about these loans'. Russell seldom interfered with the administrative work of the CDB, which suggested his strength of feeling on the subject of co-operative credit. Micks described the episode as the 'only matter that caused unpleasant friction at the Board's meetings'. Despite pressure from Russell the $\mathrm{CDB}$ still managed to direct limited funding towards the co-operative movement. At the height of the IAOS's financial quarrel with the DATI, the CDB funds provided welcome funds to defray the travelling expenses of co-operative organisers. ${ }^{66}$

The financial woes of the IAOS looked set to end when David Lloyd George, the Liberal Chancellor of the Exchequer, announced the controversial 'People's Budget' in late 1909. This budget delivered a host of measures to fund new welfare reforms and included provisions to create a Development Commission. Established in May 1910, this body encouraged the development of British resources via scientific approaches to agriculture, including the 'promotion of co-operative marketing'. The emphasis of the Development Commission lay in 'promoting the country's rural and agricultural development ${ }^{67}$ Plunkett successfully lobbied the government to insert a clause that allowed the Development Commission to fund agricultural co-operation. ${ }^{68}$ The Commission aimed to fund innovative practices but looked to achieve this through the medium of existing centres of research and expertise. ${ }^{69}$ The IAOS represented an ideal candidate for such development funds due to its fifteen years' experience in rural reform.

The IAOS immediately seized the opportunity and applied to the Development Commission for a new grant to replace the lost DATI subsidy. However, the devolution of agricultural powers to Ireland worked against the IAOS as the decision over the allocation of this new grant money resided with the DATI. The IAOS and its sister organisations, the Scottish Agricultural Organisation Society and the English Agricultural Organisation Society, applied for funding. The latter two received grants of $£ 1,000$ and $£ 3,000$ respectively. In Ireland the grant application needed to be submitted to the DATI for approval before it passed to the Development Commission. The IAOS submitted its funding application to the DATI in January 1911. Russell delayed the application process and that November refused to endorse the IAOS's claim for support. His reasoning remained the same as previous years. First, he cited the controversial and political nature of the IAOS, which became publicly associated with a hostile attitude towards the IPP. Second, he argued that 'certain trading interests in this country naturally objected to state aid being accorded to the formation of societies that were intended to enter into competition with them in the exercise of their legitimate trading operations', ${ }^{70}$

In a series of letters published in The Times that December, Plunkett addressed what he termed a crisis in rural progress and argued that Russell's actions threatened the co-operative movement's attempts to build 'a new social economy'. ${ }^{71} Æ$ made similar arguments in the Irish Homestead. While the English agricultural co-operative 
movement received the money applied for without difficulty, the IAOS struggled to survive. $Æ$ launched an appeal for donations with the hope that 'the organised farmers of Ireland will take note of the difference of treatment of the IAOS in Ireland and the AOS in England'. ${ }^{72}$ In 1911, the IAOS temporarily withheld payment of employees, who only received their wages following a donation of $£ 1,800$ by Horace Plunkett. ${ }^{73}$ Robert Anderson believed that, without Plunkett's generosity at this juncture, the IAOS would have disbanded while its application to the Development Commission lay unprocessed. ${ }^{74}$

T.W. Russell's decision to block the IAOS application reflected his support for private traders, shopkeepers and butter merchants opposed to the IAOS's role in the rural economy. He gave a revealing interview to the Co-operative News while in Glasgow the following February. In the course of the interview Russell claimed that he held no prior opinion about the IAOS and its work before he became the leader of the DATI. However, when Russell assumed office he learned that an annual department grant of $£ 3,700$ to the movement provided a major source of controversy and he was aware that the 'Irish Nationalist party charged the agents of the IAOS with working against the Nationalist cause'. The traders of Ireland also 'objected to State money, part of which they as taxpayers had to contribute, being used to oppose them in business'. Having weighed up these arguments Russell concluded that the IAOS purposefully antagonised the Nationalist Party and he could no longer justify a state subsidy to fund such a movement. When asked to elaborate further on his refusal to support the IAOS's application to the Development Commission, Russell responded: 'because the traders object as taxpayers to State money being used to cut their throats' ${ }^{75}$

The conflict with the DATI led to public declarations of support for the IAOS from a multitude of voices from outside the mainstream of Irish politics. Importantly, a younger generation that grew to maturity influenced by the ethos and creative energy unleashed by the cultural revival began to announce itself in favour of the co-operative ideal. In particular, this crisis for the IAOS encouraged declarations of support from seemingly disparate political quarters, but gathered together in one source - The Irish Review. This monthly nationalist journal showcased writing on the topics of Irish literature, science and politics, and existed for three years between 1911 and 1914. During its short life the journal exerted considerable influence upon the direction of Irish politics. It published work by writers, some of whom (including co-founder Thomas MacDonagh) became leading participants in the Easter Rising. ${ }^{76}$ The Review offered a platform for nationalists whose opinions did not fit with the parliamentary orthodoxy. Instead, the journal gave 'expression to the intellectual movement in Ireland', which encompassed a broad range of people united in their interest in 'the application of Irish intelligence to the reconstruction of Irish life'. The first editorial stressed that 'science and economics will claim an increasing share of attention as our people progress towards the command of their resources' ${ }^{77}$ The Irish 
Review aimed at an audience which anticipated some form of political autonomy against the backdrop of Home Rule negotiations, but which also wished to understand how an independent Irish society should be organised. It provided readers with a wide range of cultural and political topics to engage with, and debates about the co-operative movement's role in Irish society featured prominently. In social and economic subjects, particularly those related to agriculture, the editorial line supported co-operative methods to promote national development. Æ's "The Problem of Rural Life” appeared across its first six issues. The Irish Review acted as a useful guide to the issues concerning an emergent nationalist elite in the early twentieth century.

The cessation of state funding to the IAOS formed a dominant topic that preoccupied many contributions. James Hannay, a writer, clergyman and Gaelic League activist, more popularly known by his nom de plume, George Birmingham, rejected the parliamentary methods applied by the IPP in its pursuit of political freedom and viewed British liberalism as a hypocritical doctrine. Instead, his political philosophy led him to believe that the real national energy existed beyond the dry politicking at Westminster and arguing that 'the Gaelic League, the co-operative movement and Sinn Féin could bring about a true national revival based on individual self-reliance and free discussion'. ${ }^{78}$ Birmingham attacked Russell's policy of 'non-controversial co-operation' in The Irish Review, which he characterised as a piece of disingenuous politicking. He argued that Russell knew 'perfectly well that there is no such thing as non-controversial co-operation. All co-operation amongst farmers must provoke the hostility of someone':

Co-operative creameries excite the fury of the butter merchant. Egg societies enrage the gentlemen at present occupied in packing stale eggs in dirty straw. Even Raffeissen [sic] banks [credit societies] injure the business of the local trader whose customers are tied to him by their debts, and the publican-politician whom it suits to have a financial hold over the farmers. When Mr. [T.W.] Russell spoke of the noncontroversial co-operation which he would organise, he meant either that he would organise no co-operation at all or else that he would organise co-operation in the teeth of the protests of the very class through whose influence the money was withheld from the IAOS. ${ }^{79}$

Russell's policy excluded the co-operative movement whenever possible, but Birmingham recognised the powerful implications of a co-operative intervention for the rural community.

These debates played out against a backdrop of tense political negotiations and a potential constitutional crisis that coloured the controversy. One astute analyst of the situation made a connection between how one's support for the co-operative movement over the DATI highlighted an attitude in favour of a new, socially enlightened variant of nationalism. 'An Ulster Imperialist's' assessment of the political situation outlined various positions regarding the Home Rule debate, alongside potential political developments if a Home Rule Bill failed or 
succeeded. The author argued that if the Bill failed, nationalist Ireland threatened to divide into two camps and identified attitudes to the co-operative movement as the major fault-line:

The conflict between Nationalists of the Co-operative movement and Nationalists of the T.W. Russell party would probably split a new line of cleavage across the whole body of Irish politics, giving rise to a new party which would contain nearly all the constructive elements of Irish life ... upon an agrarian policy, and becoming inevitably a Home Rule party in which gradually ... the best of our citizens would be very much of one mind. In some way such as this, Ireland might, before the lapse of many years, arrive at a settlement of the Home Rule Question. ${ }^{80}$

This analysis of Irish nationalism proved insightful. For the anonymous 'Imperialist' the question of Home Rule and agrarian economics were intimately bound up with one another.

In the end, direct intervention came from Westminster. The Irish Chief Secretary, Augustine Birrell, personally placed the case of the IAOS before the Cabinet and cited his disapproval of Russell's actions. ${ }^{81}$ The Development Commission granted the IAOS a sum of $£ 2,000$ in 1913 through the Chief Secretary's office. In subsequent years the Commission offered a generous annual grant of up to $£ 4,000$ per annum on the basis of $£ 1$ for every $£ 1$ subscribed by members. This measure incentivised societies to contribute to the IAOS and morale soared on account of the grant, which provided financial security and offered a seal of approval for the co-operative movement's work. ${ }^{82}$

The grant's conditions introduced important limitations upon the IAOS's activities. The Commission banned the IAOS from creating co-operative retail societies and narrowed the range that forms of co-operative organisation promoted by the IAOS could take and separated the junior retailing branch of the organisation from the larger, established productive branch. The link between co-operative societies and the Dublin-based IAOS was reformed. Previously, the IAOS offered assistance to all co-operative societies, but under new conditions 'contributory affiliation' became 'a condition of receiving advice and assistance from the Society. ${ }^{83}$ While this constrained various co-operative activities, the most politically important outcome of this decision lay in the Development Commission's decision to circumvent T.W. Russell's authority. This undermined the political autonomy of the DATI and occurred while political tensions in Ireland grew evermore volatile. The fact that Westminster moved to circumvent the devolved DATI to ensure funding reached the co-operative movement revealed how officialdom viewed the IAOS's work as providing an important economic function. It also showed that Westminster's patience with Irish political independence had limitations.

The high regard in which central government held the IAOS, and the importance it placed upon its developmental role in Irish rural society, saw the British administration override the fragile devolved governmental apparatus then in place. The new funding assured the IAOS of its immediate future and guaranteed its 
continued involvement in agrarian matters despite the opposition of the DATI ${ }^{84}$ The Irish Homestead welcomed the Commission's findings as a vindication of the co-operative movement's work, describing the financial aid as a measure that allowed it to 'carry on its agricultural programme in the future as in the past'. ${ }^{85}$

An important development also materialised in the support for the co-operative programme from a new generation of voices that came to maturity immersed in the Irish Revival. New ideas emerged from a wide range of culturally nationalist groups and organisations, among which the IAOS provided a fertile source. Stephen Gwynn, an IPP MP between 1906 and 1918, noted that a younger generation of Irish nationalists preferred ideas associated with Sinn Féin to those preached by his own party. Gwynn observed with the benefit of hindsight a decade later that although a relatively small sect before 1914, 'Sinn Féin, rather than Parliamentarianism, was the growing creed, and it based its claim on different grounds and had a different outlook' ${ }^{86}$ The Sinn Féin party increasingly became a politically heterogeneous home for individuals disenchanted with the IPP's brand of politics. This 'different outlook' defined the new nationalists who would be brought under the umbrella of the Sinn Féin party after 1916.

The IAOS maintained its organisational work in the face of institutional and political obstructions and, in the process, captured the attention of foreign observers interested in agricultural development. In a 1913 submission to an American Commission investigating the condition of agricultural co-operation across Europe, the IAOS made a great claim for its work as it embedded co-operation throughout the Irish countryside. On the eve of the First World War the IAOS looked upon its achievements with satisfaction, and anticipated the next phase of a co-operative revolution: 'The hardest part of [its work] is done. The change of feeling in the country has been effected. Rural Ireland is ready to be completely organised. ${ }^{87}$

\section{Notes}

1 Æ's address, 'The Building up of a Rural Civilisation', given at the IAOS Annual Conference. The IAOS published a transcript in pamphlet form. IAOS, Annual Report, 1909, 38.

2 Paul Bew, Ideology and the Irish Question: Ulster Unionism and Irish Nationalism, 1912-1916 (Oxford: Clarendon Press, 1994); Ronan Fanning, Fatal Path: British Government and Irish Revolution 1910-1922 (London: Faber \& Faber, 2013).

3 IAOS, Annual Report, 1909, 38.

4 Horace Plunkett, New York, to Fr T.A. Finlay, Dublin, December 1909, NLI, Ms 49, 803/44/2

5 Edward E. Lysaght, Sir Horace Plunkett and his Place in the Irish Nation (Dublin: Maunsel \& Co., 1916), 17.

6 R.F. Foster, Modern Ireland, 1600-1972 (London: Penguin, 1988), 431-493.

7 Lionel Smith-Gordon and Cruise O'Brien, Co-operation in Denmark (Manchester: Co-operative Union, 1919), 24. 
8 Horace Plunkett, 'The Relations between Organized Self Help and State Aid in Ireland', North American Review, 67.503 (1898), 497-498 (p. 498).

9 David A. McCabe, 'The Recent Growth of Co-operation in Ireland', Quarterly Journal of Economics, 20.4 (1906), 547-574 (pp. 571-572).

10 IAOS, Annual Report, 1896, 6.

11 IAOS, Annual Report, 1899, 29.

12 Ciara Breathnach, The Congested Districts Board of Ireland, 1891-1923: Poverty and Development in the West of Ireland (Dublin: Four Courts Press, 2005).

13 IAOS, Annual Report, 1895, 5.

14 James Logan, Ulster in the X-Rays: A Short Review of the Real Ulster, its People, Pursuits, Principles, Poetry, Dialect and Humour (London: Arthur H. Stockwell, n.d.), 99.

15 Dermot Meleady, Redmond: The Parnellite (Cork: Cork University Press, 2008), 258-259.

16 Michael Clune, 'The Work and the Report of the Recess Committee, 1895-6', Studies, 71.281 (1982), 72-84; Carla King, 'The Recess Committee, 1895-6', Studia Hibernica, 30 (1998/1999), 21-46.

17 K. Theodore Hoppen, Governing Hibernia: British Politicians and Ireland, 1800-1921 (Oxford: Oxford University Press, 2016), 274.

18 Andrew Gailey, Ireland and the Death of Kindness: The Experience of Constructive Unionism 1890-1905 (Cork: Cork University Press, 1987), 3.

19 Mary E. Daly, The First Department: A History of the Department of Agriculture (Dublin: Institute of public Administration, 2002), 14.

20 Horace Plunkett, 'The Recess Committee and Remedial Legislation for Ireland', Economic Journal, 7.25 (1897), 131-136 (p. 134).

21 William P Coyne, 'Preface', in Ireland: Industrial and Agricultural, ed. by Department of Agriculture and Technical Instruction (Dublin: Brown and Nolan Limited, 1902), unpaginated.

22 'Surprise Butter Competition, 1905', Irish Homestead, 2 September 1905, 661.

23 Cited in R.A. Anderson, 'Agricultural Co-operation in Ireland', in Ireland: Industrial and Agricultural, ed. by Department of Agriculture and Technical Instruction (Dublin: Brown and Nolan Limited, 1902), 218-234 (pp. 233-234).

24 The social production of psychological instability remained a long-held view by many in Ireland. Both medical experts and lay people "believed that generations of emigration had siphoned off the cream and left behind a "weaker" and "vulnerable" population'. Nancy Scheper-Hughes, Saints, Scholars and Schizophrenics: Mental Illness in Rural Ireland, 2nd edn (Berkeley: University of California Press, 2001), 34-35.

25 DATI, Second Annual General Report of the Department, 1901-02 (Dublin: HMSO, 1902), 12.

26 IAOS Office Committee Meeting, 22 July 1902, Gore-Booth Papers, PRONI, $\mathrm{D} / 4131 / \mathrm{M} / 14$.

27 IAOS, Annual Report, 1904, 164-175.

28 Copy of Lismore Rural District Council Resolution, 2 July 1902; 'Agricultural Co-operation', R.A. Anderson's Circular to Rural District Councils, 19 July 1902, Gore-Booth Papers, PRONI, D/4131/M/14.

29 'Irish Clergymen and Irish Civilisation', Irish Homestead, 7 October 1905, 733-734. 
30 IAOS, Home Rule in the Dairy (Dublin: Irish Agricultural Organisation Society, 1903).

31 F.S.L. Lyons, The Irish Parliamentary Party, 1890-1910 (London: Faber, 1951), 233; John Coolahan, Irish Education: Its History and Structure (Dublin: Institute of Public Administration, 1981), 92.

32 House of Commons Parliamentary Papers [HCPP] [Cd. 3572] DATI Report of the Departmental Committee of Inquiry (1907), 120.

33 HCPP [Cd. 3574], DATI Minutes of Evidence Taken Before the Departmental Committee of Inquiry (1907), 348-349.

34 IAOS, Annual Report, 1906, 85.

35 Cited in Anderson, 'Agricultural Co-operation', 234.

36 Marianne Elliott, When God Took Sides: Religion and Identity in Ireland - Unfinished History (Oxford: Oxford University Press, 2009), 200-211.

37 Hansard HC Deb 28 November 1906 vol. 166 cc65-7, http://hansard.millbanksystems.com/ commons/1906/nov/28/subsidies-to-the-irish-agricultural\#S4V0166P0_19061128_ HOC_100 [accessed 10 June 2016].

38 Eunan O'Halpin, The Decline of the Union: British Government in Ireland, 1892-1920 (Dublin: Gill \& Macmillan, 1987), 69; Trevor West, Horace Plunkett, Co-operation and Politics (Gerrards Cross, Bucks.: Colin Smythe, 1986), 76-81.

39 James Loughlin, 'Russell, Sir Thomas Wallace', in Dictionary of Irish Biography: From Earliest Times to the Year 2002, Volume 8, ed. by James McGuire and James Quinn (Cambridge: Cambridge University Press, 2009), 665-666. On Russell's early career, see Loughlin, 'T.W. Russell, the Tenant Farmer Interest and Progressive Unionism in Ulster, 1886-1900', Eire-Ireland, 25.1 (1990), 44-63.

40 Nicholas Whyte, Science, Colonialism and Ireland (Cork: Cork University Press, 1999), 97-98.

41 IAOS, Annual Report, 1906, 85.

42 IAOS, Annual Report, 1907, 55-56.

43 IAOS, Annual Report, 1907, 57.

44 R.A. Anderson, With Horace Plunkett in Ireland (London: Macmillan and Co., 1935), 176.

45 'The Irish Co-operative Grant', The Times, 22 March 1913, 6.

46 F.S.L. Lyons, Ireland Since the Famine (London: Fontana Press, 1975), 215.

47 Anderson, With Horace Plunkett, 123; Líam Kennedy, 'Farmers, Traders and Agricultural Politics in Pre-Independence Ireland', in Irish Peasants: Violence and Political Unrest, 1780-1914, ed. by James S. Donnelly and Samuel Clark (Manchester: Manchester University Press, 1983), 339-373 (pp. 350-353).

48 T.W. Russell, 'The Vice-President's Address to the Council of Agriculture', Department of Agriculture and Technical Instruction for Ireland, 8.2 (1908), 209-226 (pp. 220-222).

49 DATI, Seventh Annual Report of the Department, 1906-07 (Dublin: His Majesty's Stationery Office, 1908), 2.

50 'In Darkest Department', Irish Homestead, 23 November 1907, 926.

51 Department of Agriculture and Technical Instruction for Ireland, Eighth Annual Report of the Department, 1907-08 (Dublin: His Majesty's Stationery Office, 1908), 35.

52 'Is Co-operation a Political Dodge?' Irish Homestead, 4 May 1907. 
53 Anderson, With Horace Plunkett, 133.

54 IAOS, Annual Report, 1907, 55-6.

55 HCPP [Cd. 1749], Committee on Butter Regulations, Final Report (1903), 3.

56 HCPP [Cd. 5092], Report of the Departmental Committee on the Irish Butter Industry (1910), unpaginated minute appointing the committee.

57 HCPP [Cd. 5093], Departmental Committee on the Irish Butter Industry, Minutes of Evidence, Appendices and Index (1910), 475.

58 HCPP [Cd. 5093], Departmental Committee, 477.

59 HCPP [Cd. 5092], Report of the Departmental Committee, 2.

60 HCPP [Cd. 5092], Report of the Departmental Committee, 19.

61 C.C. Riddall to T. O’Donovan, Abbeydorney, 19 December 1913, NAI 1088/2/2.

62 IAOS, Annual Report, 1907, 15.

63 American Commission to Investigate Agricultural Credit and Cooperation, Agricultural Cooperation and Rural Credit in Europe (Washington: Government Printing Office, 1913), 888.

64 'The Irish Co-operative Grant', The Times, 22 March 1913, 6; IAOS, Annual Report, 1911, 22.

65 IAOS, Annual Report, 1912, 22

66 William L. Micks, An Account of the Constitution, Administration and Dissolution of the Congested Districts Board for Ireland from 1891 to 1923 (Dublin: Eason \& Son, Limited, 1925), 95-96.

67 Bruce K. Murray, The People's Budget 1909/1910: Lloyd George and Liberal Politics (Oxford: Oxford University Press, 1980), 146.

68 West, Horace Plunkett, 85.

69 Bentley Brinkerhoff Gilbert, 'David Lloyd George: Land, the Budget, and Social Reform', American Historical Review, 81.5 (1976), 1058-1066 (p. 1065); Robert Olby, 'Social Imperialism and State Support for Agricultural Research in Edwardian Britain', Annals of Science, 48.6 (1991), 509-526.

70 Daly, First Department, 43.

71 Horace Plunkett, The Crisis in Irish Rural Progress: Being Three Letters Reprinted from The Times (London: John Parkinson Bland, 1912), 1-3.

72 'The Position of the IAOS', Irish Homestead, 2 September 1911, 688-689.

73 West, Horace Plunkett, 86.

74 Anderson, With Horace Plunkett, 175.

75 'Irish Agricultural Organisation', Co-operative News, 17 February 1912, 188-189.

76 W.J. McCormack, Dublin 1916: The French Connection (Dublin: Gill \& Macmillan, 2012), 74-96.

77 Editor, '[Untitled Introduction]', The Irish Review 1.1 (1911), 1-6 (p. 1).

78 Patrick Maume, 'Hannay, James Owen (“George A Birmingham”)', in Dictionary of Irish Biography: From Earliest Times to the Year 2002, Volume 4, ed. by James McGuire and James Quinn (Cambridge: Cambridge University Press, 2009), 444-448 (p. 445).

79 George A. Birmingham, 'Politics in the Nude', Irish Review, 1.10 (1911), 469-476 (p. 471).

80 Ulster Imperialist, 'An Appreciation of the Situation', Irish Review, 2.13 (1912), 1-11 (p. 9). 
81 Margaret Digby, Horace Plunkett: An Anglo-American Irishman (Oxford: Basil Blackwell, 1949), 146.

82 West, Horace Plunkett, 86.

83 HCPP [Cd. 6735], Copy of Treasury Letter, dated 1st April, 1913, Respecting the Conditions on which a Grant will be made to the [Irish Agricultural Organisation] Society, from the Development Fund (1913).

84 Patrick Bolger, The Irish Co-operative Movement: Its History and Development (Dublin: Institute of Public Administration, 1977), 105-106; Kennedy, 'Farmers, Traders and Agricultural Politics', 351-353.

85 'The IAOS and the Development Commission', Irish Homestead, 19 July 1913, 593-594.

86 Stephen Gwynn, Ireland (London: Ernest Benn, 1924), 97.

87 American Commission, Agricultural Cooperation, 888. 